\title{
A THERMOGRAVIMETRIC STUDY OF REDUCTION OF SILVER OXIDE UNDER NON-ISOTHERMAL CONDITIONS
}

\author{
D. Jelić ${ }^{1, *}$, S. Mentus ${ }^{2,4}$, J. Penavin- Skundrić $^{3}$, D. Bodroža ${ }^{3}$, B. Antunović ${ }^{1}$ \\ ${ }^{1}$ University of Banja Luka, Faculty of Medicine, Department of Pharmacy, \\ Republic of Srpska, B\&H \\ ${ }^{2}$ University of Belgrade, Faculty of Physical Chemistry, Belgrade, Serbia \\ ${ }^{3}$ University of Banja Luka, Faculty of Technology, Department of General \\ and Inorganic Chemistry, Republic of Srpska, B\&H \\ ${ }^{4}$ Serbian Academy of Sciences and Arts, Belgrade, Serbia
}

\begin{abstract}
Thermal decomposition of a commercial powder of silver oxide $\left(\operatorname{Ag}_{2} \mathrm{O}\right.$, Merck, p.a.), with the mean particle diameter of $740 \mathrm{~nm}$ has been investigated under nonisothermal conditions in a reducing atmosphere of $25 \% \mathrm{H}_{2}$ in argon. The process was conducted and controlled in a simultaneous TG/DTA analyzer, at heating rates of 2, 10 and $20{ }^{\circ} \mathrm{C} \mathrm{m^{-1 }}$. The residual mass was always around $93,2 \%$ of the initial one, regardless of the heating rate, which, according to the oxide stoichiometry, corresponds to metallic silver as final product. The SEM microphotography indicated no significant change in particle size and morphology during reduction. The thermogravimetric data was used for kinetic analysis of reduction. Using Kissinger plot, the initial value of the activation energy was estimated to amount to $6.17 \cdot 10^{4} \mathrm{~J} \mathrm{~mol}^{-1}$. The initial values for kinetics parameters were further calculated using different methods of kinetic analysis. Both activation energy $(E)$ as a function of conversion degree $(\alpha)$, and pre-exponential factor $(A)$ were calculated by either the Friedman $\left(E a=5,38 \cdot 10^{4} \mathrm{~J} \mathrm{~mol}^{-1}, A=1,49 \cdot 10^{6} \mathrm{~s}^{-1}\right)$ or multi-heating rate CoastRedfern $\left(E a=5,97 \cdot 10^{4} \mathrm{~J} \mathrm{~mol}^{-1}, A=3,90 \cdot 10^{5} \mathrm{~s}^{-1}\right)$ isoconversional methods. A rather complex dependence of activation energy on the conversion degree was observed. A more complete approach to determine the kinetic parameters was done by means of nonlinear regression analysis $\left(E a=6,00 \cdot 10^{4} \mathrm{~J} \mathrm{~mol}^{-1}, A=2,41 \cdot 10^{6} \mathrm{~s}^{-1}, n=0,466\right)$.
\end{abstract}

Keywords: silver oxide, non-isothermal kinetics, isoconversional methods, reduction process, thermogravimetry.

\section{INTRODUCTION}

The field of nanoscience has blossomed over last two decades and it is developing more and more with ability to synthesize nanoparticles of various materials, different in size and shape. Nanoscience finds wide application in catalysis, optical devices, humidity sensors, computing, biomedical researches, etc.[1]

The main techniques of synthesis of nanostructures include direct growth methods, vapour-liquid-solid mechanism and the so-called soft-chemistry methods like sol-gel synthesis, chemical precipitation and hydrothermal treatment [2].

Nanoparticles often exhibit unusual physical and chemical properties that are different from either simple molecules or bulk materials [1,3].

Recently, precious metal nanoparticles have been extensively investigated due to their unique catalytic, electronic, optical, mechanical, magnetic and chemical properties. The unique properties could be attributed to their small size and large specific surface area [3]. Materials containing silver may be applied in many areas of technology, and related literature offers numerous methods for synthesis of fine Ag particles. A common method to produce Ag particle is Lee-Meisel method that uses silver nitrate as initial substance [4]. This method produces particles of non-uniform sizes. Ag particles incorporated in porous solid matrices were produced through high temperature reduction and vapor-phase condensation on the solid support [3].

$\mathrm{AgO}$ and $\mathrm{Ag}_{2} \mathrm{O}$ are two thermodynamically stable oxides of silver. $\mathrm{AgO}$ is most commonly used as a cathode material for zinc-silver oxide "button cell" batteries, serving as the power source for many small electronic devices [5]. Silver alone is extensively used in heterogeneous catalysis and high performance materials science. Catalysts containing silver oxide are efficient for decomposition of ozone $[6,7]$ 
and halo-organic compounds [8]. The catalysts for carbon monoxide and numerous other volatile organic compounds (VOCs) oxidation based on $\mathrm{Ag}_{2} \mathrm{O}$ are also well known [9]. Thermally regenerable solid sorbents of $\mathrm{CO}$ and $\mathrm{H}_{2} \mathrm{O}$ containing $\mathrm{Ag}_{2} \mathrm{O}$ have been developed for air-purification systems in aerospace vehicles $[10,11]$

In recent years nanoparticles of silver have been found to exhibit interesting antibacterial activities. Because of their high reactivity due to the large surface to volume ratio, nanoparticles play a crucial role in inhibiting bacterial growth in aqueous and solid media. Silver containing materials can be employed to eliminate microorganisms on textile fabrics $[12,13]$ as well as for water treatment [14] Silver oxide is also used as ionic modifier in fast-ion conducting glasses [15].

There is not a great deal of information in literature about the kinetics of the reduction of $\mathrm{Ag}_{2} \mathrm{O}$ by hydrogen. The aim of this paper was to obtain pure silver particles by reduction of silver oxide $\mathrm{Ag}_{2} \mathrm{O}$ in hydrogen flow in non-isothermal conditions, using an advanced thermoanalytical technique, and to determine kinetic triplet: $E a, \ln A$ and $f(\alpha)$ of the reduction process.

\section{EXPERIMENTAL PROCEDURES}

\section{1. Materials}

Silver (I) oxide, $\mathrm{Ag}_{2} \mathrm{O}$ p.a., was used as purchased from Merck.

The gaseous mixture for oxide reduction consisted of $25 \% \mathrm{H}_{2}+$ Ar mixture. The source was highpressure tank purchased from Messer. Purity of gases was $99,995 \mathrm{vol} \%$.

\section{2. Thermal analysis of $\mathrm{Ag}_{2} \mathrm{O}$ in reducing atmosphere}

Reduction of $\mathrm{Ag}_{2} \mathrm{O}$ samples was estimated by simultaneous thermogravimetry and differential thermal analysis, using the TA SDT Model 2060 device. The flow rate of reducing gas was $100 \mathrm{~mL} / \mathrm{min}$. Thermal decomposition was observed in non-isothermal conditions at several selected heating rates: 2 , 10 and $20^{\circ} \mathrm{C} / \mathrm{min}$.

\section{3. Characterisation of $\mathrm{Ag}_{2} \mathrm{O}$ and Ag samples}

The particle size and morphology of samples before and after reduction powders was analysed by means of scanning electron microscope (SEM) JEOL JSM-6390 LV.

\section{METHODS OF KINETIC ANALYSIS}

A common starting point in the kinetic analysis based on thermal analysis data [16] is the following equation:

$$
\frac{d \alpha}{d t}=k f(\alpha)=A e^{-E / R T} f(\alpha)
$$

whereby $\alpha$ is the conversion degree, $t$ is time, $f(\alpha)$ is a mathematical expression the form of which is dependent on the reaction mechanism, and $k=A \exp (-$ $E / R T)$, whereby $A$ is the pre-exponential factor, $E_{\mathrm{a}}$ is the apparent activation energy and $R$ the gas constant.

The exact determination of kinetic parameters is based on multiple scan methods, which requires the measurements at different heating rates, and uses the data sampled at common conversion degrees (isoconversion, model-free methods). There are several isoconversion methods: the Ozawa-Flynn-Wall method, the Kissinger-Akahira-Sunsone method [17] and the expanded Friedman method [16]. These methods allow checking the invariance of $E$ with respect to $\alpha$, which is one of the basic assumptions in kinetic analysis. Once the $E_{\alpha}$ is determined, it is possible to search for the function (kinetic model) $f(\alpha)$ which enables the best match of experimental data. Among them, the expanded Friedman method, given by Eq. 2 , was used more frequently [16]:

$$
\ln \left(\frac{d \alpha}{d t_{\alpha}}\right)=-\frac{E_{\alpha}}{R T_{\alpha}}+\ln \left\{A_{\alpha} f(\alpha)\right\}
$$

Here $t_{\alpha}, T_{\alpha}, E_{\alpha}$ and $A_{\alpha}$ are time, temperature, apparent activation energy and pre-exponential factor, respectively, at a given conversion degree $\alpha$. The slope of the plot $\ln \left(\mathrm{d} \alpha / \mathrm{dt}_{\alpha}\right)$ vs. $1 / T_{\alpha},-E_{\alpha} / R$, and the intercept of this plot with the vertical axis, enable to determine the activation energy, $-E_{\alpha}$ and the value $\ln \left\{A_{\alpha} f(\alpha)\right\}$, respectively. In addition, it is possible to predict the parameters at any temperature, by means of the values $E_{\alpha}$ and $\left\{A_{\alpha} f(\alpha)\right\}$ extracted from Eq. 2, if they were introduced into Eq. 1 modified in the following way [16]:

$$
t_{\alpha}=\int_{0}^{t_{\alpha}} d t=\int_{0}^{\alpha} \frac{d \alpha}{\left\{A_{\alpha} f(\alpha)\right\} e^{E_{\alpha} / R T_{0}}}
$$

No specification of the exact form of the reaction model $f(\alpha)$ is needed for such an analysis. Eq. 2 and Eq. 3 present a complete base for all of the Friedman isoconversional kinetic measurements and 
predictions. Introducing the heating rate, $\beta$, as a parameter which correlates time and temperature, Eq. 1 can be alternatively written as:

$$
g(\alpha)=\frac{d \alpha}{f(\alpha)}=\int_{0}^{T_{0}} \frac{A}{\beta} \exp \left(-\frac{E}{R T}\right) d T
$$

The modified Coasts-Redfern method [16] is a multi-heating rate application of the Coast-Redfern equation, resulting in a model-free isoconversional approach, similar to that of Friedman. It is based on the equation [16]:

$$
\ln \left[\frac{\beta}{T^{2}(1-2 R T / E a)}\right]=-\frac{E a}{R T}+\ln \left(-\frac{A R}{E a \ln (1-\alpha)}\right)
$$

To use this equation, at a selected common value of conversion degree for different heating rates, the left-hand side should be plotted vs. 1/T, giving a family of straight lines of slope $-E_{\alpha} / R$, while the intercept with vertical axis presents the pre-exponential factor $A$. If the values of $E_{\alpha}$ vary with the variation of $\alpha$, the results should be interpreted in terms of multi-step reaction mechanism. The Friedman method [16] applies to any thermal history while the modified Coast-Redfern applies only to a constant heating rate. The Kissinger method ( $\mathrm{Li}$ and Tang, Burnham $[18,19])$ is a special isoconversion case, serving to determine the initial values of $A$ and $E_{\alpha}$. The method is based on the plot $\ln \left(\beta / T_{\max }{ }^{2}\right)$ vs. $1 / T_{\max }$ whereby $T_{\max }$ is the temperature at which, for a given heating rate, conversion rate exceeds its maximum. The slope of this plot amounts to $-E_{\alpha} / R$.

Calculations based on the above-mentioned methods were performed by means of the software Kinetics05. Kinetics05 is an advanced kinetic tool, which offers nine different models range from a single first-order reaction to a variety of activation energy distribution models. The values of asymmetry and relative profile width are very helpful to determine which model is the most appropriate as well as to estimate initial values for regression analysis. The fields of applicability for the various models are given in Figure 1.

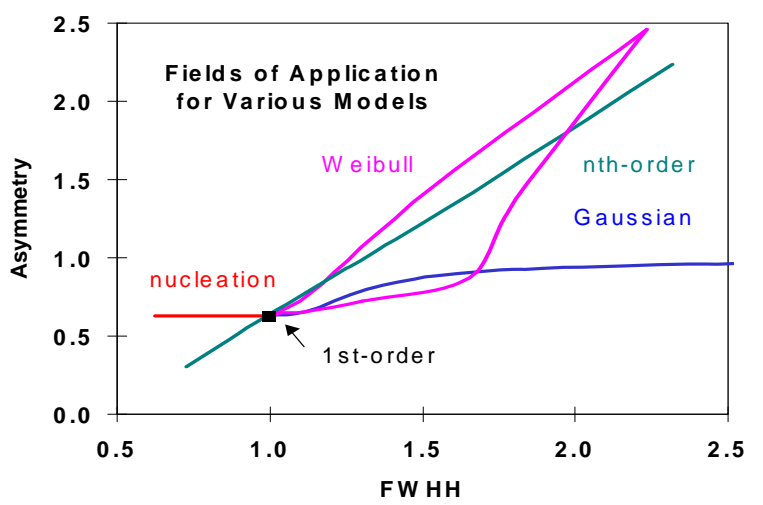

Figure 1. Kinetics05 software available models

\section{RESULTS AND DISCUSSIONS}

The morphology and particle dimensions before and after silver oxide reduction were observed by SEM. The reduction product was taken directly from the thermogravimetric pan, upon cooling to room temperature. Initial sample of silver oxide had particle diameter ranging $0,74-1.21 \mu \mathrm{m}$ with irregular participle morphology. As the micrographs (Figure 2) show, there is no big difference in metal silver morphology or in particle dimensions in comparison to the initial $\mathrm{Ag}_{2} \mathrm{O}$ sample. However, one may perceive the sintering of metallic powder to some extent. The temperature used for thermogravimetric analysis of reduction did not exceed $250^{\circ} \mathrm{C}$, thus, these results indicate that mobility of silver atoms produced by oxide reduction is rather high, and enables rapid interchange of atoms between metal particles, and even sintering.
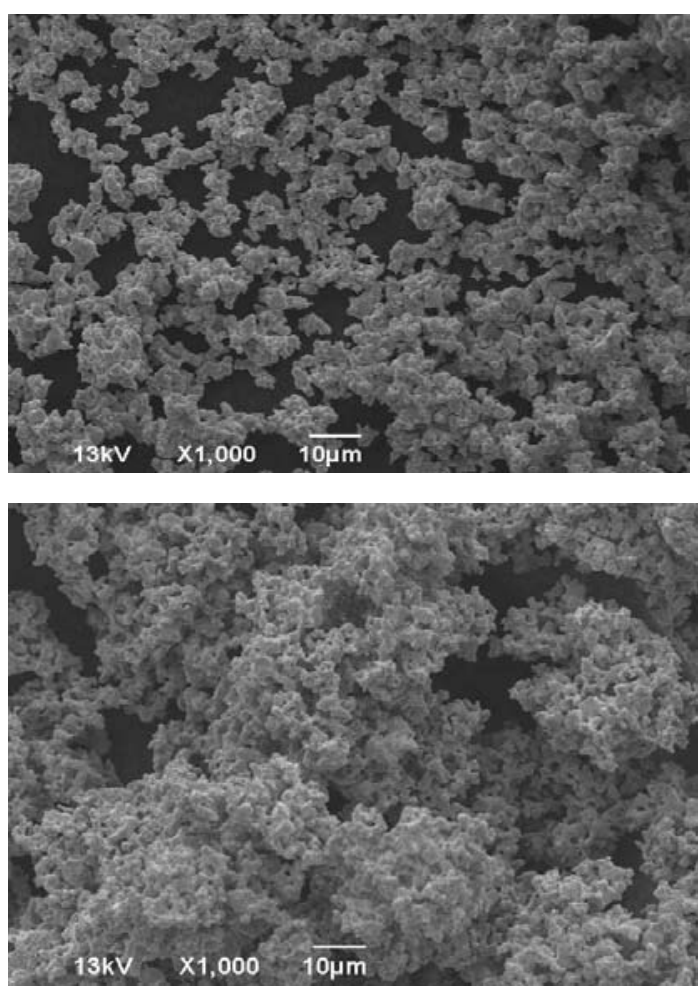

Figure 2. SEM micrographs of initial $\mathrm{Ag}_{2} \mathrm{O}$ sample (above), and the product of its reduction-metallic silver (down)

In order to investigate this reduction process from the kinetic point of view, advanced thermoanalytical technique was used. Since the use of single heating rate data is insufficient for accurate determination of kinetic parameters, the data at three heating rates was collected [20]. Figure 3 presents the TG curves of silver oxide powder under $25 \% \mathrm{H}_{2}$ and $\mathrm{Ar}$ atmosphere at the heating rates 2,10 and $20{ }^{\circ} \mathrm{C} / \mathrm{min}$. 


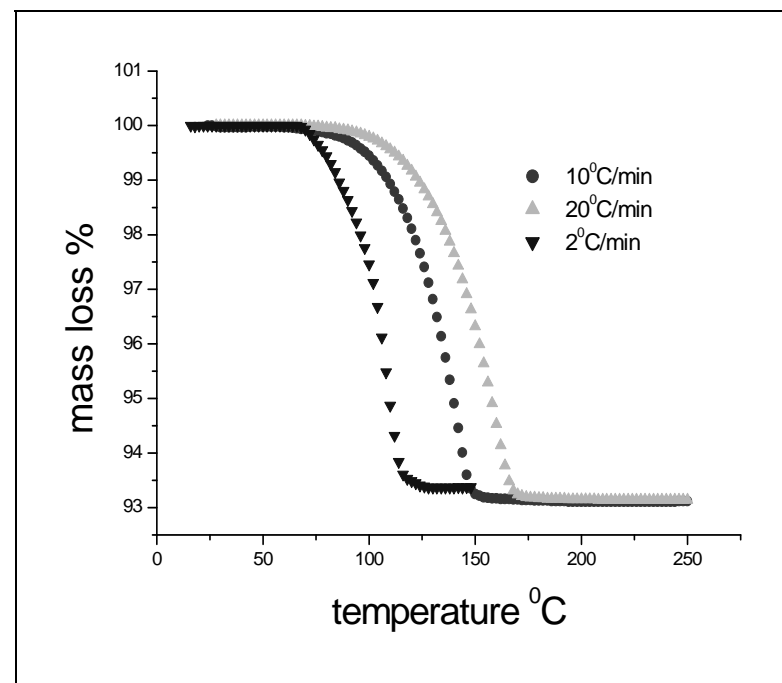

Figure 3. TG curves for reduction of $\mathrm{Ag}_{2} \mathrm{O}$ at 2, 10 and $20^{\circ} \mathrm{C} / \mathrm{min}$

The residual mass was always around 93,2\% of the initial one, regardless of the heating rate, which, according to the oxide stoichiometry, corresponds well to the decomposition to metallic silver. Figure 4 presents simultaneous TG and DTA curve recorded at a heating rate of $10{ }^{\circ} \mathrm{C} / \mathrm{min}$. At a first glance, taking into account the shape of the curves, one can conclude that the reduction of silver oxide is a single step process. In order to start the kinetics analysis of the reduction process, the initial values of kinetic parameters were determined using modified

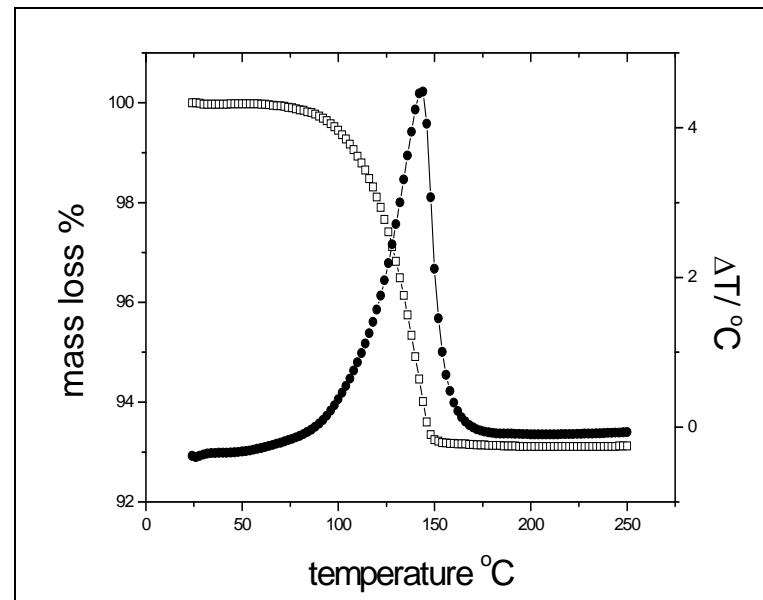

Figure 4. Simultaneuous TG and DTA curve of reduction process of $\mathrm{Ag}_{2} \mathrm{O}$ at heating rate $10^{\circ} \mathrm{C} / \mathrm{min}$.

Kissinger method. Kissinger plot (Figure 5) was done using the data for $T_{\max }$ at various heating rates, listed in Table 1. From the slop and intercept, the values $E_{\alpha}$ and $A$ were determined to amount to $E_{\alpha}=$ $6,17 \cdot 10^{4} \mathrm{~J} \mathrm{~mol}^{-1}$ and $A=6.1 \cdot 10^{5} \mathrm{~s}^{-1}$, respectively. In order to apply isoconversional methods, it was ne- cessary to transform thermogravimetric mass loss data into the conversion degree data $(\alpha)$ by means of the equation:

$\alpha=\frac{m_{0}-m_{t}}{m_{0}-m_{f}}$

whereby $m_{t}$ represents the actual mass of the sample at arbitrary time $t$ (or temperature $T$ ), whereas $m_{0}$ and $m_{f}$ are the initial and the final masses, respectively.

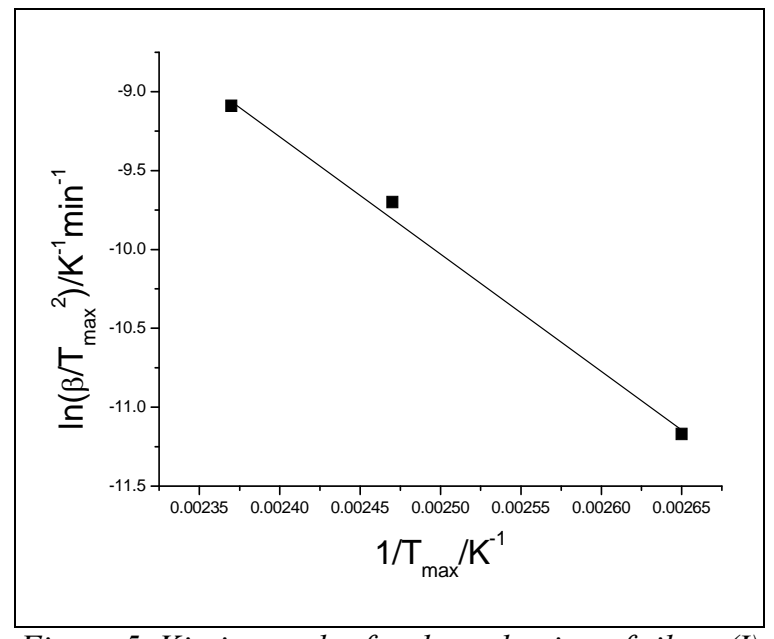

Figure 5. Kissinger plot for the reduction of silver (I) oxide

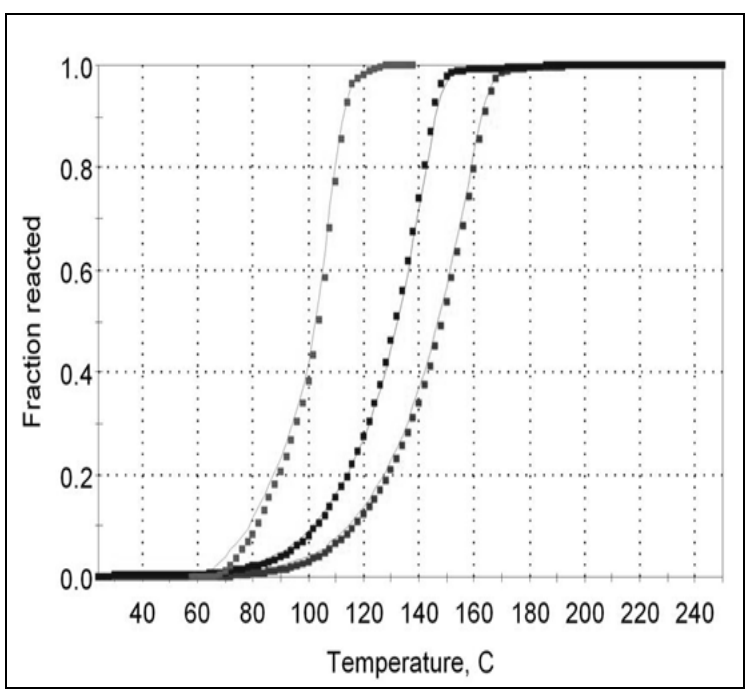

Figure 6. The dependence of conversion degree of $\mathrm{Ag}_{2} \mathrm{O}$ reduction on temperature, at heating rates (from left to right) 2, 10 and $20^{\circ} \mathrm{C} / \mathrm{min}$ by isoconversional method

Figure 6 presents the conversion degree (reacted fraction of $\mathrm{Ag}_{2} \mathrm{O}$ ) in function of temperature. Using Friedman method and modified Coast-Redfern method, the following results were obtained, $E_{\alpha}$ $=5.38 \cdot 10^{4} \mathrm{~J} \mathrm{~mol}^{-1}, A=1.49 \cdot 10^{6} \mathrm{~s}^{-1}$ and $E_{\mathrm{a}}=5.97 \cdot$ $10^{4} \mathrm{~J} \mathrm{~mol}^{-1}, A=3.90 \cdot 10^{5} \mathrm{~s}^{-1}$, respectively. The $\alpha-T$ curves for different heating rates indicate that reduction process does not occur below $60{ }^{\circ} \mathrm{C}$ for the lowest heating rate employed. It is visible that the du- 
ration of this induction period rises with the rise in heating rate. In Fig. 7 the dependence of the activation energy (left axis), as well as the dependence of $\ln A-\alpha$ (right axis) on the conversion degree is presented. As it can be seen, dependence is quite complex, practically there is no area where activation energy does not depend on $\alpha$. This type of behaviour corresponds to a quite complex process, requiring an additional kinetic analysis. This means that the values reported above should be reproduced by means of an appropriate kinetic model. In order to find a proper kinetic model for the investigated process, the width (FWHH) and asymmetry of the reaction profile are analysed by means of the software Kinetics $05^{20}$. The calculated data are listed in Table 1 for each heating rate. Figure 8 presents the comparison of experimental reaction rates (full lines) and calculated reaction rates in the function of temperature, obtained by the use of Friedman isoconversional method.

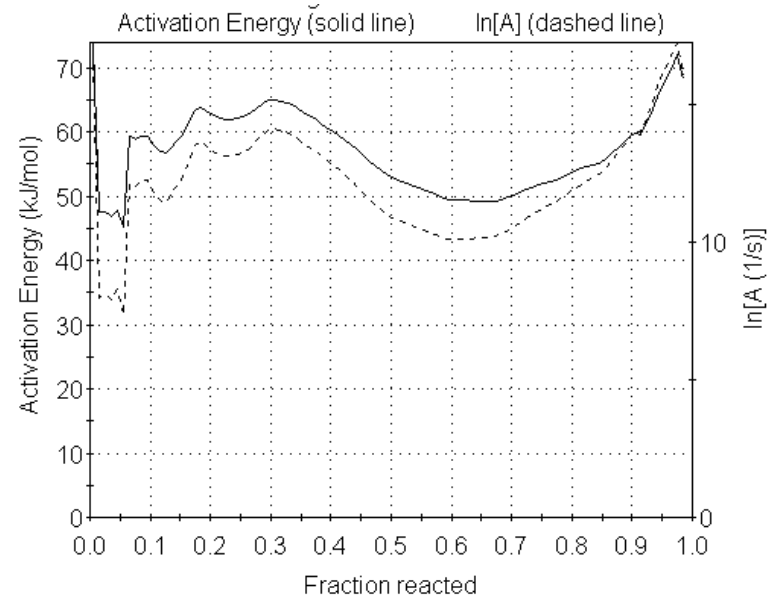

Figure 7. Dependence of activation energy and $\ln A$ on the conversion degree, for $\mathrm{Ag}_{2} \mathrm{O}$ reduction, determined by isoconversional method

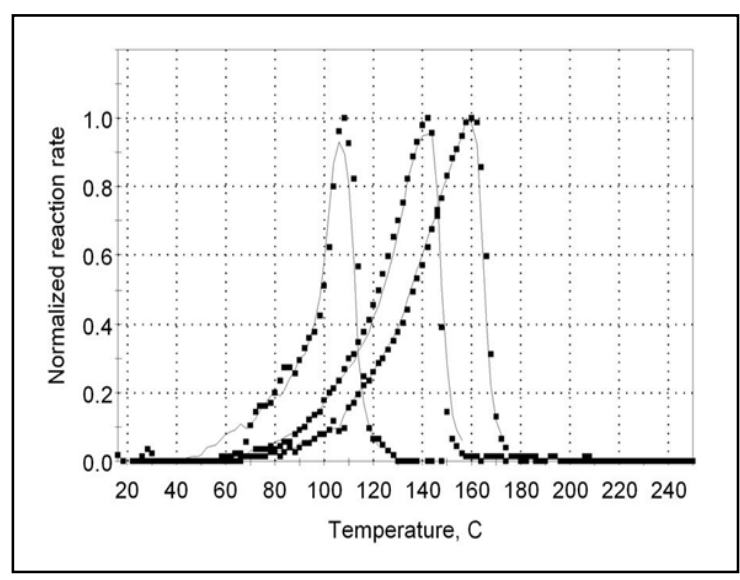

Figure 8. Experimental rate functions (full lines) and function calculated using isoconversional method for $\mathrm{Ag}_{2} \mathrm{O}$ reduction
Table 1. Data for $\mathrm{FWHH}$ and asymmetry for $\mathrm{Ag}_{2} \mathrm{O}$ sample

\begin{tabular}{|c|c|c|c|c|c|c|}
\hline Data & $\begin{array}{c}\text { Heat. } \\
\text { rate } \\
{ }^{\circ} \mathrm{C} / \mathrm{min}\end{array}$ & Tmax & $\begin{array}{c}\text { Exp. } \\
\text { FWHH }\end{array}$ & $\begin{array}{c}\text { Cal. } \\
\text { FWHH }\end{array}$ & $\begin{array}{c}\text { Exp./ } \\
\text { Calc. }\end{array}$ & Asymmetry \\
\hline 1. & 2 & 103,98 & 21,03 & 33,62 & 0,6255 & 0,4096 \\
\hline 2. & 10 & 131,61 & 27,55 & 38,88 & 0,7085 & 0,4707 \\
\hline 3. & 20 & 148,39 & 31,06 & 41,46 & 0,7491 & 0,4847 \\
\hline
\end{tabular}

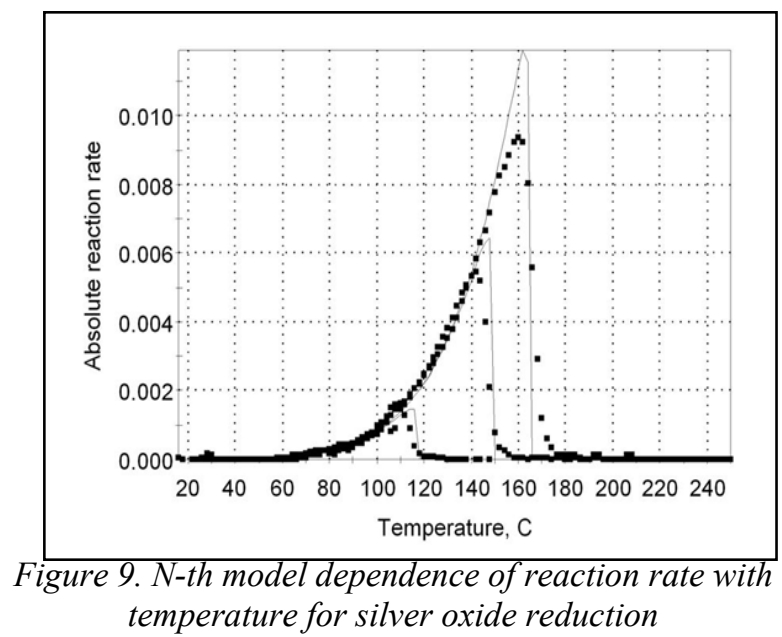

As a result of fitting process, with the help of data given in Table 1, as well as statistical data the process of silver oxide reduction is described in the best way by reaction model $\mathrm{N}$-th order. $\mathrm{N}$-th order gave the following parameters: $E_{\mathrm{a}}=6,00 \cdot 10^{4} \mathrm{~J} / \mathrm{mol}^{-1}$, $A=2,41 \cdot 10^{6} \mathrm{~s}^{-1}, n=0,466$. On the basis of obtained results by $\mathrm{N}$-th order model, the reduction of silver oxide can be described with the following differential form, i.e.roughly $f(\alpha)=(1-\alpha)^{1 / 2}$.

This type of behaviour is characteristic for phase-boundary controlled reaction, and supports the conclusion that the reaction takes place mainly at the interface of the $\mathrm{Ag}_{2} \mathrm{O}$ and $\mathrm{Ag}$. The reduction rate is proportional to the phase interfacial area. Figure 9 presents dependence of reaction rate with temperature obtained by the $\mathrm{N}$-th order model.

The Table 2 summarizes the results of entire kinetic study. As one can see, the value of activation energy obtained by modified Kissinger method agrees well with values obtained by isoconversional methods and $\mathrm{N}$-th order model.

Table 2. Results of kinetic study of silver oxide reduction

\begin{tabular}{|c|c|c|}
\hline Method & $\begin{array}{c}\text { Activation } \\
\text { energy } \mathrm{kJ} / \mathrm{mol}- \\
\mathrm{Ag}_{2} \mathrm{O}-\text { sample }\end{array}$ & $\begin{array}{c}\text { Pre-exponential } \\
\text { factor s }{ }^{-1} \\
\mathrm{Ag}_{2} \mathrm{O} \text {-sample }\end{array}$ \\
\hline Kissinger & 61,70 & $3,90 \cdot 10^{5}$ \\
\hline Friedman & 53,80 & $1,49 \cdot 10^{6}$ \\
\hline $\begin{array}{c}\text { Modified } \\
\text { Coast-Redfern }\end{array}$ & 59,70 & $3,90 \cdot 10^{5}$ \\
\hline N-th model & 60,00 & $2,41 \cdot 10^{6}$ \\
\hline
\end{tabular}




\section{CONCLUSIONS}

Kinetics of the reduction of silver(I) oxide in hydrogen atmosphere has been studied under nonisothermal conditions by thermogravimetry. Silver oxide samples during thermal decomposition gave as a product, metallic silver which was confirmed on the basis of the mass loss, $93,2 \%$, regardless of the heating rate employed.

Scanning electron microscopy showed that it was possible to determine the mean diameter of particles, which before reduction was in range 740 $\mathrm{nm}-1,21 \mu \mathrm{m}$, and did not change substantially upon reduction to metal state.

The initial values of kinetics parameters were estimated by Kissinger method, taking into account different heating rates, and the values $E_{\mathrm{a}}=6,17 \cdot 10^{4}$ $\mathrm{Jmol}^{-1}$ and $A=6.1 \cdot 10^{5} \mathrm{~s}^{-1}$ were found. The more reliable values were determined by isoconversional Friedman and multi-heating modified Coast-Redfern method. These methods, allow determining the activation energy in function of the conversion degree and/or temperature, regardless of the actual reaction model.

The following values were obtained by Friedman method: $E_{\alpha}=53.8 \mathrm{~kJ} \mathrm{~mol}^{-1}, A=1,49 \cdot 10^{6} \mathrm{~s}^{-1}$ While the Coast-Redfern method gave $E_{\alpha}=59.7 \mathrm{~kJ} \mathrm{~mol}^{-1}$, $A=3,90 \cdot 10^{5} \mathrm{~s}^{-1}$.

As the results show, there is a considerable variation of activation energy with variation in the conversion degree. This leads to a conclusion that one deals with a rather complex process. Therefore, the kinetic parameters obtained were additionally verified involving profile width and peak asymmetry as the tools to estimate the kinetic model which corresponds optimally to the process under consideration.

It was found that the most appropriate model was $\mathrm{N}$-th order model with following parameters: $E_{\alpha}=6,00 \cdot 10^{4} \mathrm{~J} \mathrm{~mol}^{-1}, A=2,41 \cdot 10^{6} \mathrm{~s}^{-1}, n=0,466$.

On the basis of this reaction model, the reduction of $\mathrm{Ag}_{2} \mathrm{O}$ samples is interface-controlled process, characterised by a rapid formation of a uniform layer of the reduced product $[21,22]$ This means that a continuous reduced-phase/oxide interface entirely covers the reactant particles, and that the rate of oxide reduction is proportional to the area of the interface [21-23].

\section{REFERENCES}

[1] D. D. Evanoff Jr., G. Chumanov, Synthesis and Optical Properties of Silver Nanoparticles and Arrays, Chem. Phys.Chem, 6 (2005) 1221-1231.
[2] T. George, S. Joseph and S. Mathew, Synthesis and characterisation of nanophased silver tungstate, J. Metastable and Nanocrystalline Materials, 23 (2005) 141.

[3] M. Mazur, Electrochemically prepared silver nanoflakes and nanowires, Electrochemistry Communications 6 (2004) 400-403.

[4] P. C. Lee, D. J. Meisel, Adsorption and surface-enhanced raman dyes on silver and gold sols, Phys. Chem., 86 (1982) 3391-3395.

[5] G. R. Graybill, R. K. Grubbs, J. A. Gucinnski and D. F. Smith, New developments in very high rate silver oxide electrodes, J. Power Sources, 65 (1997) 47.

[6] S. Imamura, M. Ikebata, T. Ito and T. Ogita, Decomposition of ozone on a silver catalyst, Ind. Eng. Chem. Res. 30 (1991) 217 B.

[7] B. Dhandapani and S. T. Oyama, Gas phase ozone decomposition catalysts, Appl. Catal. B. 11 (1997) 129.

[8] K. Kiyono and K. Shiragami, Jpn. Pat. 10099 (1998) 646.

[9] M. Luo, X. Yuan and X. Zheng, Catalyst characterization and activity of Ag-mn, $\mathrm{Ag}-\mathrm{Co}$ and Ag-Ce composite oxides for oxidation of volatile organic compounds, Appl. Catal. A.175 (1998)121.

[10] P. J. Birbara and T. A. Nallete, US Pat. 5 174 (1992) 974.

[11] J. R. Aylard, P. J. Birbara and T. A. Nalette, US Pat. 5427 (1995) 751.

[12] J. J. Zhu, X. H. Liao, X. N. Zhao, H. Y. Hen, Preparation of silver nanorods by electrochemical methods, Materials Letters 49 (2001) 91-95.

[13] R. Pacios, R. Marcilla, C. Pozo-Gonzalo, J. A. Pomposo, H. Grande, J. Aizpurua, D. Mecerreyes, Combined electrochromic and plasmonic optical responses in conductivity polymer/metal nanoparticle films, J. Nanosci. Nanotechnology 7 (2007) 2938-2941.

[14] W. L. Chou, D. G. Yu, M. C. Yang, The preparation and characterization of silver-loading cellulose acetate hollow fiber membrane for water treatment, Polym. Adv.Techn. 16 (2005) 600-608.

[15] A. Abousehly, R. El-mallaway and E. Yousef, Interaction of a polycrystalline silver powder with ozone, J. Mater. Sci. Lett. 19 (2000) 409.

[16] A. K. Burnham, L. N. Dinh, $A$ comparation of isoconversional and model-fitting approaches to kinetic parameter estimation and application prediction, J. of Therm. A. and Cal. 89/2 (2007) 479-490.

[17] T. Akahira, T. Sunsone, Joint convention of four electrical institutes, Res. Rep. Chiba, Inst.Tech. 16 (1971) 22-31. 
[18] H. E. Kissinger, Reaction kinetics in differential thermal analysis, Anal. Chem. 29 (1957) 1702 .

[19] C.-R. Li, T. B. Tang, A new method for analyzing non-isotherma thermoanalytical data from solid state reaction, J. Thermal Anal. 49 (1997) 1243.

[20] M. Maciejewski, Computitional aspects of kinetics analysis part B: The ICTAC kinetics project, Thermochimica Acta 355 (2000) 145.154.
[21] B. Delmon, In Handbook of Heterogeneous Catalysis; G. Ertl, H. Knözinger, J. Weitkamp, Eds.; (1997) 264.

[22] B. Delmon, Introduction á la cinétique hétérogéne, Technip: Paris, 1969, Chapter 11.

[23] H. H. Kung, Transition Metal Oxides: Surface Chemistry and Catalysis, Elsevier: New York 1989.

\section{ТЕРМОГРАВИМЕТРИЈСКО ИСПИТИВАЬЕ РЕДУКЦИЈЕ СРЕБРО-ОКСИДА У НЕИЗОТЕРМАЛНИМ УСЛОВИМА}

Сажетак: Термално разлагање комерцијалног праха сребро-оксида $\left(\mathrm{Ag}_{2} \mathrm{O}\right.$, Merck, p.a.) са честицама средње величине $740 \mathrm{~nm}$ проучавано је у неизотермалним условима у редукционој атмосфери од $25 \%$ водоника у аргону. Процес је вођен и контролисан у уређају за комбиновану термалну анализу TG/DTA, на брзинама загријевања 2,10 и $20^{\circ} \mathrm{C} \mathrm{min}^{-1}$. Крајња маса узорка је увијек износила око $93,2 \%$ (без обзира на брзину загријавања) од почетне вриједности масе узорка, што, на основу стехиометријског састава оксида, одговара металном сребру као крајњем продукту. SEM слике сребра послије редукције оксида показују да током редукције не долази до значајне промјене у величини честица и њиховој морфологији. Тремогравиметријски подаци употребљени су за кинетичку анализу редукције. Почетна вриједност активационе енергије одређена је Kissinger-овом кривом и износила је $6,17 \cdot 10^{4} \mathrm{~J} \mathrm{~mol}^{-1}$. Тачније вриједности кинетичких параметара су израчунате кориштењем различитих диференцијалних метода кинетичке анализе. Активациона енергија у зависности од степена конверзије $\alpha$ и предекспоненцијални фактор $A$ су одређени сљедећим изоконверзионим методама: Friedman-ова $\left(E a=5,38 \cdot 10^{4} \mathrm{~J} \mathrm{~mol}^{-1}, A=1,49 \cdot 10^{6} \mathrm{~s}^{-1}\right)$ и Coast-Redfern-ова $\left(E a=5,97 \cdot 10^{4} \mathrm{~J} \mathrm{~mol}^{-1}, A=3,90 \cdot 10^{5} \mathrm{~s}^{-1}\right)$. Показана је комплексна зависност активационе енергије од степена конверзије. Детаљнија анализа кинетичких патаметара урађена је кориштењем нелинеарних регресионих метода $\left(E a=6,00 \cdot 10^{4} \mathrm{~J} \mathrm{~mol}^{-1}\right.$, $\left.A=2,41 \cdot 10^{6} \mathrm{~s}^{-1}, n=0,466\right)$.

Кључне ријечи: сребро-оксид, неизотермална кинетика, изоконверзиони методи, редукција, термогравиметрија. 